\title{
Pathogens in Crassostrea ariakensis and other Asian oyster species: implications for non-native oyster introduction to Chesapeake Bay
}

\author{
J. A. Moss' ${ }^{1}$, E. M. Burreson ${ }^{1}$, J. F. Cordes ${ }^{1}$, C. F. Dungan ${ }^{2}$, G. D. Brown ${ }^{1}$, A. Wang ${ }^{3}$, \\ X. Wu ${ }^{4}$, K. S. Reece ${ }^{1, *}$ \\ ${ }^{1}$ Virginia Institute of Marine Science, The College of William and Mary, Gloucester Point, Virginia 23062, USA \\ ${ }^{2}$ Maryland Department of Natural Resources, Cooperative Oxford Laboratory, Oxford, Maryland 21654, USA \\ ${ }^{3}$ School of Marine Science, Hainan University, 58 Renmin Street, Haikou, Hainan 570228, PR China \\ ${ }^{4}$ College of Animal Sciences, Zhejiang University, 38 Zheda Road, Hangzhou, Zhejiang Province 310027, PR China
}

\begin{abstract}
With the drastic decline of eastern oyster Crassostrea virginica populations in the Chesapeake Bay due to over-fishing, diseases and habitat destruction, there is interest in Maryland and Virginia in utilizing the non-native oyster species Crassostrea ariakensis for aquaculture, fishery resource enhancement, and ecological restoration. The International Council for the Exploration of the Sea (ICES) recommends that non-native species be examined for ecological, genetic and disease relationships in the native range prior to a deliberate introduction to a new region. Therefore, a pathogen survey of $C$. ariakensis and other sympatric oyster species was conducted on samples collected in the PR China, Japan and Korea using molecular diagnostics and histopathology. Molecular assays focused on 2 types of pathogens: protistan parasites in the genus Perkinsus and herpesviruses, both with known impacts on commercially important molluscan species around the world, including Asia. PCR amplification and DNA sequence data from the internal transcribed spacer region of the rRNA gene complex revealed the presence of 2 Perkinsus species not currently found in USA waters: $P$. olseni and an undescribed species. In addition, 3 genetic strains of molluscan herpesviruses were detected in oysters from several potential C. ariakensis broodstock acquisition sites in Asia. Viral gametocytic hypertrophy, Chlamydia-like organisms, a Steinhausia-like microsporidian, Perkinsus sp., Nematopsis sp., ciliates, and cestodes were also detected by histopathology.
\end{abstract}

KEY WORDS: Asia · Crassostrea ariakensis • Crassostrea hongkongensis · Crassostrea gigas • Perkinsus olseni · Molluscan herpesviruses · Steinhausia sp. · Parasites · ISH · PCR

\section{INTRODUCTION}

The eastern oyster Crassostrea virginica is important both economically and ecologically in Chesapeake Bay, USA. Oyster populations have been in a severe state of decline in recent decades, due to combined effects of over-harvesting, habitat loss and disease pressures from marine pathogens (Mann et al. 1991). In the Commonwealth of Virginia, oyster landings exceeding 6 million bushels ( 1 bushel $=35.24$ l) in the 1930s have declined to less than 20000 bushels since the 1990s (NRC 2003, Allen 2005). In 1995, a Virginia General Assembly resolution requested that the Virginia Institute of Marine Science (VIMS) determine the appropriate legal process for, and examine the feasibility of, introducing a non-native oyster species to enhance ecological benefits and revitalize the oyster industry in the Chesapeake Bay region. Initial results of research using the Pacific oyster C. gigas, which has been successfully introduced at several locations around the world, suggested that this oyster species would not perform well in the Chesapeake Bay (Calvo 
et al. 1999). The search for another non-native oyster species that might be more suitable for the regional conditions was therefore initiated.

Considerable interest has recently focused on the Suminoe oyster Crassostrea ariakensis, which resembles the native oyster C. virginica in taste (Grabowski et al. 2003), and is tolerant of temperate to subtropical water temperatures and variable salinities. Field trials conducted in Virginia waters have documented lower mortality and faster growth in the Suminoe oyster, as compared with the native oyster. Disease surveys of triploid Suminoe oysters deployed in these parallel trials also suggest that in comparison to the native eastern oyster, $C$. ariakensis is relatively resistant to Haplosporidium nelsoni and Perkinsus marinus infections (Calvo et al. 2001, Orner 2005), the 2 major parasites that have decimated $C$. virginica oyster populations in Chesapeake Bay since the 1950s (Sindermann 1990).

Based on significant impacts that non-native introductions of various aquatic species have had around the world, the International Council for the Exploration of the Seas (ICES) developed a 'Code of Practice on Introductions and Transfers of Marine Organisms' (ICES 2005). The code describes a series of protocols to be followed prior to introductions of exotic animals. A thorough review of the ecological, genetic and disease impacts on native bivalves of the proposed introduced species in its natural range and in source locations is recommended. These and similar recommendations from other organizations were the impetus behind a survey that we conducted on the parasites of Crassostrea ariakensis and other sympatric oyster species in the native range of $C$. ariakensis in China, Japan and Korea.

Previous research has documented the harmful impact of both Perkinsus spp. and herpes-like viruses on molluscan species in Asia (Choi \& Park 1997, Park \& Choi 2001, Chang et al. 2005). This fact, along with the availability of molecular assays for these organisms (Renault et al. 2000a, Casas et al. 2002), prompted us to specifically screen for these pathogens in Asian oyster populations. Since the discovery of Perkinsus marinus in Crassostrea virginica along the Gulf of Mexico and Atlantic coasts of the USA in the late 1940s and early 1950s (Mackin et al. 1950, Ray 1952), Perkinsus spp. have been found worldwide, and many are reported to cause disease in commercially important mollusc species. P. marinus is notorious for its devastating effects on Atlantic and Gulf of Mexico, USA oyster populations (Andrews \& Hewatt 1957, Burreson \& Ragone Calvo 1996). In the Chesapeake Bay region, $P$. chesapeaki (= P. andrewsi) (Burreson et al. 2005) has been associated with disease outbreaks in Mya arenaria and Tagelus plebeius (Dungan et al. 2002). Clam and oys- ter mortalities have also occurred in conjunction with Perkinsus spp. infections on the Atlantic and Mediterranean coasts of Europe (Da Ros \& Cazonier 1985, Azevedo 1989, Figueras et al. 1992, Santmartí et al. 1995, Montes et al. 2001, Villalba et al. 2005), in Australia (Lester \& Davis 1981, Goggin \& Lester 1995) and in Korea (Choi \& Park 1997, Park \& Choi 2001).

In addition to Perkinsus spp. parasites, viruses and particularly molluscan herpesviruses have been found to cause massive mortality, mainly in hatchery-reared larvae and juvenile animals, leading to severe economic losses (Hine et al. 1992, Le Deuff et al. 1994, Arzul et al. 2001, Friedman et al. 2005). Numerous cases of herpes-like viruses affecting commercial marine molluscs have been reported around the world, the earliest in 1972 in Crassostrea virginica in Maine, USA (Farley et al. 1972). Herpes-like viruses have been reported in the Pacific oyster C. gigas (Hine et al. 1992, Nicolas et al. 1992, Renault et al. 1994, Friedman et al. 2005), the European flat oyster Ostrea edulis (Comps \& Cochennec 1993, Renault et al. 2000a), the Australian flat oyster O. angasi (Hine \& Thorne 1997), larvae of the Chilean oyster Tiostrea chilensis in New Zealand (Hine et al. 1998), the European carpet shell clam Ruditapes decussatus (Renault et al. 2001), the Manila clam $R$. philippinarum, (Renault 1998) and the scallop Pecten maximus in France (Arzul et al. 2001). A similar herpes-like virus may be responsible for mortality events in abalone Haliotis diversicolor supertexta in Taiwan (Chang et al. 2005).

Unlike the larvae and some juvenile oysters, adult Crassostrea gigas appear capable of surviving asymptomatically with Ostreid herpes virus-1 (OsHV-1) infections (Arzul et al. 2002), with no gross physiological signs detectable prior to death in the infected individuals. Histopathological signs indicative of infection include enlarged and abnormally shaped cell nuclei, and abnormal chromatin patterns throughout the connective tissue (Renault et al. 1994). The experience in French hatcheries has shown that this pathogen is likely to be vertically transmitted from broodstock to progeny, and can be very difficult to eradicate from facilities (Arzul et al. 2001). Consequently, if introduced along with $C$. ariakensis, molluscan herpesviruses could have a devastating impact on the remaining $C$. virginica populations in Chesapeake Bay, and on the growing aquaculture industry in the USA mid-Atlantic region.

In accordance with the ICES (2005) recommendation that non-native species be examined for diseases in their native range prior to a deliberate introduction into a new region, we conducted a pathogen survey of Crassostrea ariakensis and other sympatric oyster species in samples collected in China, Japan and Korea. Perkinsus spp. and other metazoan parasites were 
observed by histology. Molecular diagnostics developed to target Perkinsus spp. and OsHV-1 identified 2 Perkinsus species not currently found in USA waters (P. olseni and an undescribed Perkinsus species), as well as 3 genetic variants of molluscan herpesviruses that are highly similar in DNA sequence to OsHV-1 in the genomic region analyzed. It should be noted that recent studies using these same molecular diagnostic assays have detected the 2 endemic Perkinsus species, $P$. marinus and $P$. chesapeaki in waters of eastern North America (Burreson et al. 2005, Audemard et al. 2006). No evidence of molluscan herpesviruses, however, has been detected in bivalve hosts along the Atlantic and Gulf of Mexico coasts of the USA (Friedman et al. 2005).

\section{MATERIALS AND METHODS}

Sample collection and preparation. Samples of Crassostrea ariakensis and, inadvertently, several other oyster species (see below), were collected from coastal sites in China, Japan and Korea between 1999 and 2005 (Fig. 1 and Table 1). Additional oyster hemolymph samples were taken from hatchery-reared $C$. ariakensis including F1 northern China $C$. ariakensis

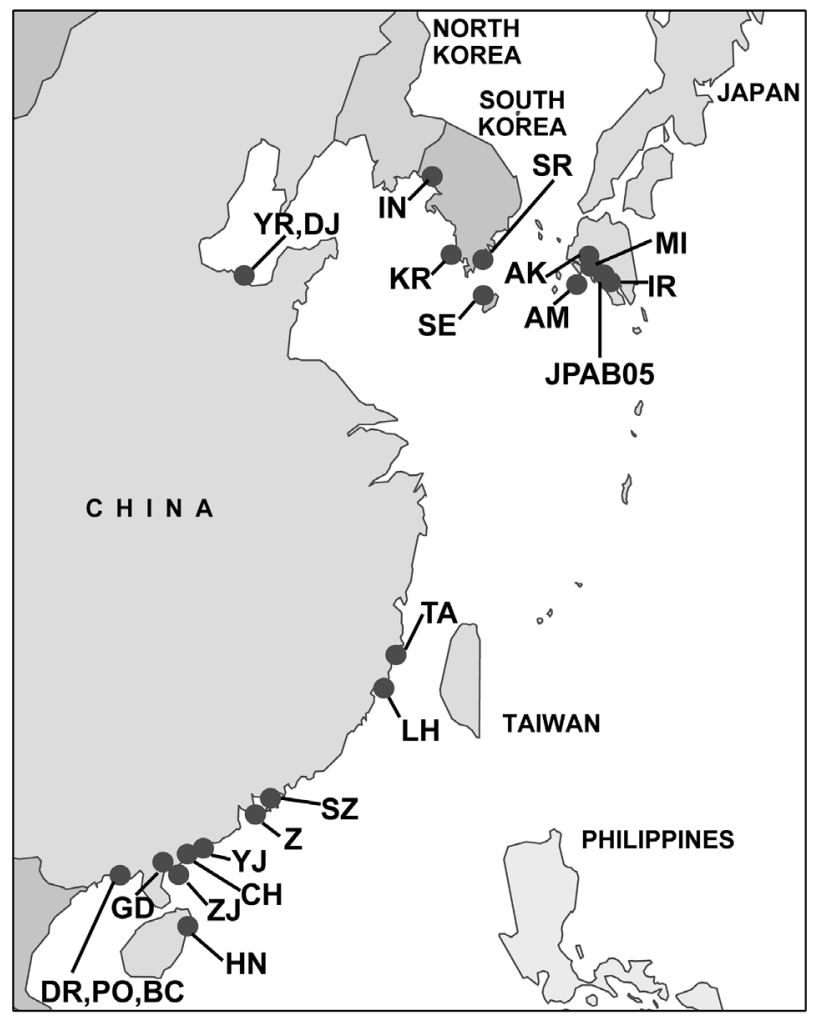

Fig. 1. Map of sampling locations. See Table 1 for site abbreviations
(NCA) spawned from broodstock collected from the Yellow River in China in 1999, F1 southern China C. ariakensis (SCA) spawned from broodstock collected from the Dafen River in China in 1999, and west coast USA C. ariakensis (WCA) spawned from broodstock imported to VIMS from Washington, USA in 1999. Adductor muscle, mantle, gill tissue and/or hemolymph from each individual were preserved in either DMSO (25 mM EDTA, $20 \%$ DMSO and saturated $\mathrm{NaCl}$ ) or $95 \%$ ethanol for DNA extraction and PCR analysis. When samples were additionally preserved and processed for histological analysis (Table 1), a sterile blade was used to excise a transverse tissue section through the visceral mass, and histological samples were fixed in Davidson's solution (Shaw \& Battle 1957). Because of the large size of the oysters in the 2002 Chinese samples, 2 tissue sections were preserved for each animal, one that included digestive gland, gill and mantle, and one that included adductor muscle, heart and kidney. Paraffin wax-infiltrated histological tissues were embedded, sectioned at 5 to $6 \mu \mathrm{m}$ thickness, and sections were stained with Mayer's hematoxylin and eosin for microscopic analyses.

Nucleic acid extraction. Genomic DNA was extracted individually for each oyster from excised mantle and gill snips using the DNeasy ${ }^{\circledR}$ Tissue Kit (Qiagen) following manufacturer's protocols. Hemolymph samples were centrifuged at $16000 \times \mathrm{g}$ for $5 \mathrm{~min}$ and precipitated floccules were then subjected to DNA extraction with the DNeasy ${ }^{\circledR}$ Tissue Kit. DNA was eluted in 50 to $200 \mu \mathrm{l}$ of elution buffer.

Test for amplifiable DNA. In order to ensure that amplifiable DNA was present in all extracted samples, genomic DNAs were tested using universal small subunit ribosomal RNA (SSU-rRNA) gene primers 16SA (5'-CCGAATTCGTCGACAACCTGGTTGATCCTGCCAGT-3') and 16S-B (5'-GGATCCAAGCTTGATCCTTCTGCAGGTTCCCTAC-3') (modified from Medlin et al. 1988) with an expected amplification product of approximately $1800 \mathrm{bp}$. Each PCR reaction contained the following: $20 \mathrm{mM}$ Tris- $\mathrm{HCl}(\mathrm{pH} 8.4), 50 \mathrm{mM} \mathrm{KCl}$, $0.75 \mathrm{mM} \mathrm{MgCl}_{2}, 0.1 \mathrm{mM}$ of each dNTP, $0.5 \mu \mathrm{M}$ of each primer, $0.0125 \mathrm{U} \mathrm{ul}^{-1}$ Taq polymerase, $0.2 \mathrm{mg} \mathrm{ml}^{-1}$ bovine serum albumin (BSA), and $0.5 \mu$ genomic DNA (10 to $50 \mathrm{ng}$ total). Amplifications were performed with an initial denaturation of $94^{\circ} \mathrm{C}$ for $4 \mathrm{~min}$, followed by 35 cycles at $94^{\circ} \mathrm{C}$ for $30 \mathrm{~s}, 45^{\circ} \mathrm{C}$ for $30 \mathrm{~s}, 65^{\circ} \mathrm{C}$ for $2 \mathrm{~min}$, with a final elongation at $65^{\circ} \mathrm{C}$ for 2 min. Following amplification, $3 \mu \mathrm{l}$ of PCR product were analyzed by agarose gel electrophoresis $(2 \%)$, stained with ethidium bromide and visualized under UV light. Images were recorded with an Alpha Innotech FluorChem ${ }^{\circledR}$ imaging system.

Genus-specific Perkinsus spp. PCR assay. Screening for Perkinsus spp. DNA was performed using Perkin- 
Table 1. Sampling sites, abbreviations used, sample sizes, bivalve species present, analyses performed and general results (+ or -) of assays. Sampling sites in China are ordered from northern to southern locations, and are listed chronologically for multiple collections from a single site. Positive (+) assay results in the molecular assays indicate that either molluscan herpesvirus or Perkinsus sp. DNA was detected (see Table 2) and, for the histological analysis, that a potential pathogen was detected (see Table 3$) . C .=$ Crassostrea, $\mathrm{SCA}=\mathrm{F} 1$ southern China $C$. ariakensis, $\mathrm{NCA}=\mathrm{F} 1$ northern China $C$. ariakensis, WCA $=$ west coast USA C. ariakensis

\begin{tabular}{|c|c|c|c|c|c|c|}
\hline Year & $\begin{array}{l}\text { Sampling location } \\
\text { (sample abbreviation) }\end{array}$ & $\begin{array}{l}\text { Natural }(\mathrm{N}) \\
\text { ultivated }(\mathrm{C})\end{array}$ & $\begin{array}{l}\text { Sample } \\
\text { size }(N)\end{array}$ & $\begin{array}{l}\text { Oyster } \\
\text { species }\end{array}$ & $\begin{array}{l}\text { Assays } \\
\text { performed }\end{array}$ & $\begin{array}{l}\text { Assay results } \\
\quad(+ \text { or }-)\end{array}$ \\
\hline \multicolumn{7}{|l|}{ Japan } \\
\hline 1999 & Itoki River, Kyushu (IR) & $\mathrm{N}$ & 50 & C. ariakensis & Molecular & + \\
\hline 2003 & Ariake Sea (AK) & $\mathrm{N}$ & 24 & C. gigas, C. sikamea & Molecular & - \\
\hline 2004 & Amakusa (AM) & $\mathrm{N}$ & 60 & C. gigas & Molecular & - \\
\hline 2004 & Midori (MI) & $\mathrm{N}$ & 68 & C. gigas & Molecular & - \\
\hline 2005 & Mie Prefecture (JPAB05) & $\mathrm{C}$ & 246 & $\begin{array}{c}\text { C. ariakensis, C. sikamea, } \\
\text { C. gigas }\end{array}$ & Molecular & + \\
\hline \multicolumn{7}{|c|}{ South Korea } \\
\hline 2004 & Seogwipo (SE) & Unknown & 161 & $\begin{array}{c}\text { Saccostrea sp., C. gigas, } \\
\text { unknown sp. }\end{array}$ & Molecular & - \\
\hline 2004 & Kahwa River (KR) & Unknown & 35 & C. ariakensis, C. gigas & Molecular & + \\
\hline 2004 & Sumjin River (SR) & Unknown & 20 & C. ariakensis & Molecular & + \\
\hline 2004 & $\begin{array}{l}\text { Kanghwa Island, } \\
\text { Inchon (IN) }\end{array}$ & Unknown & 20 & C. ariakensis & Molecular & + \\
\hline \multicolumn{7}{|c|}{ PR China (PRC) } \\
\hline 1999 & $\begin{array}{l}\text { Yellow River, Bohai Sea, } \\
\text { Shandong (YR) }\end{array}$ & $\mathrm{N}$ & 43 & C. ariakensis & Molecular & + \\
\hline \multirow[t]{2}{*}{2002} & Dajiawa, Shandong (DJ) & $\mathrm{N}$ & 26 & C. ariakensis, & Molecular & - \\
\hline & & & & C. hongkongensis & Histological & - \\
\hline \multirow[t]{2}{*}{2002} & Longhai, Fujian (LH) & $\mathrm{C}$ & 9 & C. hongkongensis & Molecular & - \\
\hline & & & & & Histological & + \\
\hline \multirow[t]{2}{*}{2002} & Tong'an, Fujian (TA) & $\mathrm{N}$ & 28 & C. ariakensis, & Molecular & - \\
\hline & & & & C. hongkongensis & Histological & + \\
\hline 1999 & $\begin{array}{l}\text { Yamen River, Zhuhai, } \\
\text { Guangdong (Z) }\end{array}$ & $\mathrm{N}$ & 50 & C. hongkongensis & Molecular & + \\
\hline 1999 & $\begin{array}{l}\text { Shouchang River, Yangjiang, } \\
\text { Guangdong (YJ) }\end{array}$ & g, & 50 & C. hongkongensis & Molecular & + \\
\hline \multirow[t]{2}{*}{2002} & Chengcun, Yangxi, & $\mathrm{C}$ & 37 & C. ariakensis, & Molecular & + \\
\hline & Guangdong (CH) & & & C. hongkongensis & Histological & + \\
\hline \multirow[t]{2}{*}{2002} & Shenzhen, Guangdong & $\mathrm{N}$ & 13 & C. ariakensis, & Molecular & + \\
\hline & (SZ) & & & C. hongkongensis & Histological & + \\
\hline \multirow[t]{2}{*}{2002} & Guandu, Zhanjiang, & $\mathrm{C}$ & 35 & C. hongkongensis & Molecular & + \\
\hline & Guangdong (GD_C) & & & & Histological & + \\
\hline 2002 & $\begin{array}{l}\text { Guandu, Zhanjiang, } \\
\text { Guangdong (GD_N) }\end{array}$ & $\mathrm{N}$ & 25 & C. hongkongensis & $\begin{array}{l}\text { Molecular } \\
\text { Histological }\end{array}$ & $\begin{array}{l}+ \\
+\end{array}$ \\
\hline 2003 & Zhanjiang, Guangdong (ZJ) & $\mathrm{C}$ & 71 & $\begin{array}{l}\text { C. ariakensis, } \\
\text { C. hongkongensis }\end{array}$ & Molecular & + \\
\hline 1999 & $\begin{array}{l}\text { Dafen River, Beihai, } \\
\text { Guangxi Zhuang (DR) }\end{array}$ & $\mathrm{N}$ & 50 & $\begin{array}{l}\text { C. ariakensis, } \\
\text { C. hongkongensis }\end{array}$ & Molecular & + \\
\hline \multirow[t]{2}{*}{2002} & Dafen River, Beihai, & $\mathrm{N}$ & 17 & C. ariakensis, & Molecular & - \\
\hline & Guangxi Zhuang (DR_02) & & & C. hongkongensis & Histological & + \\
\hline \multirow[t]{2}{*}{2002} & Podi, Beihai, & $\mathrm{C}$ & 39 & C. ariakensis, & Molecular & + \\
\hline & Guangxi Zhuang (PO) & & & C. hongkongensis & Histological & + \\
\hline 2003 & $\begin{array}{l}\text { Beihai, Guangxi Zhuang } \\
\text { (BC) }\end{array}$ & $\mathrm{N}$ & 64 & $\begin{array}{l}\text { C. ariakensis, } \\
\text { C. hongkongensis }\end{array}$ & Molecular & $\begin{array}{l}+ \\
+\end{array}$ \\
\hline \multirow[t]{2}{*}{2005} & Beihai, Guangxi Zhuang & $\mathrm{N}$ & 113 & C. ariakensis, & Molecular & + \\
\hline & (BC_05) & & & C. hongkongensis & Histological & - \\
\hline 2003 & $\begin{array}{l}\text { Lingshui, Hainan, Guangxi } \\
\text { Zhuang (HN) }\end{array}$ & $\mathrm{C}$ & 19 & $\begin{array}{l}\text { Pinctada margaritifera, } \\
\text { P. martensii, unknown sp. }\end{array}$ & Molecular & + \\
\hline \multicolumn{7}{|c|}{ USA hatchery stocks } \\
\hline 2000 & $\begin{array}{l}\text { SCA hatchery (SCA) } \\
\text { (F1 of DR, PRC) }\end{array}$ & $\mathrm{C}$ & 52 & $\begin{array}{l}\text { C. ariakensis, } \\
\text { C. hongkongensis }\end{array}$ & Molecular & - \\
\hline 2002 & $\begin{array}{l}\text { NCA hatchery (NCA) } \\
\text { (F1 of YR, PRC) }\end{array}$ & $\mathrm{C}$ & 50 & C. ariakensis & Molecular & + \\
\hline 2003 & WCA hatchery (WCA) & $\mathrm{C}$ & 49 & C. ariakensis & Molecular & + \\
\hline
\end{tabular}


sus genus-specific primers that target the internal transcribed spacer (ITS) region of the rRNA gene complex (modified slightly from Casas et al. 2002), specifically PerkITS-85 (5'-CCGCTTTGTTTGGATCCC-3') and PerkITS-750 (5'-ACATCAGGCCTTCTAATGATG-3'). Each PCR reaction contained the following: $20 \mathrm{mM}$ Tris- $\mathrm{HCl}$ (pH 8.4), $50 \mathrm{mM} \mathrm{KCl}, 1.5 \mathrm{mM} \mathrm{MgCl}_{2}$, $0.2 \mathrm{mM}$ of each dNTP, each primer at $1.0 \mu \mathrm{M}, 0.025 \mathrm{U}$ $\mathrm{ul}^{-1}$ Taq polymerase, $0.05 \mathrm{mg} \mathrm{ml}^{-1} \mathrm{BSA}$, and $0.5 \mu \mathrm{l}$ genomic DNA (10 to $50 \mathrm{ng}$ total). Amplifications were performed with an initial denaturation of $95^{\circ} \mathrm{C}$ for $4 \mathrm{~min}$ followed by 40 cycles of $95^{\circ} \mathrm{C}$ for $1 \mathrm{~min}, 53^{\circ} \mathrm{C}$ for $1 \mathrm{~min}, 65^{\circ} \mathrm{C}$ for $3 \mathrm{~min}$, with final elongation at $65^{\circ} \mathrm{C}$ for 5 min. Following amplification, $4 \mu \mathrm{l}$ of PCR product were analyzed as described above.

Molluscan herpesvirus PCR assay. The 'A' region of the molluscan herpesvirus genome encoding a gene of unknown function (Batista et al. 2007) was amplified using nested 'A' region primer pairs (Renault et al. 2000 b). First a product of approximately $1000 \mathrm{bp}$ was amplified, followed by an approximate 900 bp product in the nested reaction. For the A3 (5'-GCCAACCGTTGGAACCATAACAAGCG-3')/A4 (5'-GGGAATGAGGTGAACGAAACTATAGACC-3') primer pair (external primers), the PCR reaction contained the following: $20 \mathrm{mM}$ Tris- $\mathrm{HCl}$ (pH 8.4), $50 \mathrm{mM} \mathrm{KCl}, 1.0 \mathrm{mM}$ $\mathrm{MgCl}_{2}, 0.4 \mathrm{mg} \mathrm{ml}^{-1} \mathrm{BSA}, 0.8 \mathrm{mM}$ of each dNTP, 0.24

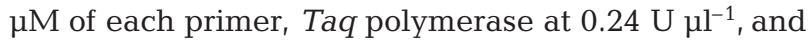
template DNA at $20 \mathrm{ng} \mathrm{ll}^{-1}$. Amplifications were performed with an initial denaturation at $94^{\circ} \mathrm{C}$ for $4 \mathrm{~min}$, followed by 35 cycles of $94^{\circ} \mathrm{C}$ for $4 \mathrm{~min}, 50^{\circ} \mathrm{C}$ for $30 \mathrm{~s}$, and $72^{\circ} \mathrm{C}$ for $30 \mathrm{~s}$, with final elongation at $72^{\circ} \mathrm{C}$ for 5 min. Reaction conditions and reagent concentrations were the same for the internal amplification reaction using the A5 (5'-CGCCCCAACCACGATTTTTCACTGACCC-3')/A6 (5'-CCCGTCAGATATAGGATGAGATTTG-3') primer pair, however $0.5 \mu$ of the initial PCR reaction after the A3/A4 amplification was used in the A5/A6 reaction in place of genomic DNA. Following amplification using the A5/A6 primers, $5 \mu$ of PCR product were analyzed by agarose gel electrophoresis as described above.

In situ DNA probe hybridization (ISH) assays. Paraffin wax-infiltrated tissues from 2 different animals, one collected from Podi, Beihai, China, in 1999, and another collected from Beihai, China, in 2005, were cut into $5 \mu \mathrm{m}$ sections for in situ hybridization assays. A genus-specific, 5' digoxigenin-labeled genus-Perkinsus probe (Elston et al. 2004) was used to target unique SSU-rRNA sequences of Perkinsus spp. Digoxigenin-labeled oligonucleotides were obtained from Operon Biotechnologies. The ISH protocol of Stokes \& Burreson (1995) was followed, with the modifications of Elston et al. (2004). Pronase at a final concentration of $1.25 \mathrm{mg} \mathrm{ml}^{-1}$ was used for permeabiliza- tion during a 30 min incubation. A probe concentration of $7 \mathrm{ng}^{-1} \mathrm{l}^{-1}$ was used for hybridization. An anti-digoxigenin antibody linked to alkaline phosphatase was used in conjunction with NBT/BCIP for colorimetric detection of bound probe. Negative controls included duplicate histological sections of all tested samples, which received hybridization buffer without probe during hybridization incubations.

PCR-RFLP identification of oyster host species. Species identification of host oyster samples were carried out using a molecular diagnostic key based on the PCR amplification and restriction enzyme digestion of the ITS-1 gene region (Cordes \& Reece 2005). PCR amplifications were carried out using the primers of Hedgecock et al. (1999). The PCR reaction contained the following: $20 \mathrm{mM}$ Tris- $\mathrm{HCl}$ (pH 8.4), $50 \mathrm{mM} \mathrm{KCl}, 1.5 \mathrm{mM}$ $\mathrm{MgCl}_{2}, 0.2 \mathrm{mM}$ of each dNTP, $0.1 \mu \mathrm{M}$ of each primer,

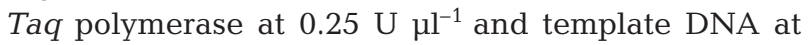
$0.2 \mathrm{ng} \mathrm{\mu l}^{-1}$. Amplifications were performed with an initial denaturation at $95^{\circ} \mathrm{C}$ for $3 \mathrm{~min}$, followed by 30 cycles of $95^{\circ} \mathrm{C}$ for $1 \mathrm{~min}, 52^{\circ} \mathrm{C}$ for $2 \mathrm{~min}$, and $72^{\circ} \mathrm{C}$ for $2 \mathrm{~min}$, with a final elongation at $72^{\circ} \mathrm{C}$ for $5 \mathrm{~min}$. Amplification products were digested with the diagnostic restriction enzymes HaeIII or DdeI following manufacturer's protocols (New England Biolabs). Following amplification and digestion, $4 \mu \mathrm{l}$ of the initial PCR product and $10 \mu \mathrm{l}$ of the digested PCR product were electrophoresed on a $3 \%(1.5 \%$ agarose and $1.5 \%$ low-melt agarose) agarose gel, stained with ethidium bromide, and visualized under UV light. Banding patterns were compared to those of reference oyster species for species identifications.

Cloning and sequencing. PCR products of the Perkinsus spp. ITS region, and those amplified by primers designed to target OsHV-1 sequences, were cloned into the plasmid $\mathrm{pCR}^{\circledR} 4-\mathrm{TOPO}{ }^{\circledR}$ and transformed into Escherichia coli using a TOPO TA Cloning ${ }^{\circledR}$ Kit (Invitrogen) following the manufacturer's protocols. Transformed bacterial colonies were screened for inserts using a boil-preparation method, followed by a PCR-based screening reaction using the M13 forward and reverse primer pairs supplied in the cloning kit, or by ECoRI digest following plasmid DNA isolation.

When using the EcoRI digest method, $4 \mathrm{ml}$ of $2 \mathrm{YT}$ media were inoculated with transformed bacterial colonies and incubated for 12 to $15 \mathrm{~h}$ in a water bath at $37^{\circ} \mathrm{C}$ while shaking at $200 \mathrm{rpm}$. Plasmid DNA was purified from bacterial cultures using a Qiaprep Spin Miniprep Kit (Qiagen) and electrophoresed on a 2\% agarose gel. EcoRI restriction digestions were performed in $15 \mu \mathrm{l}$ reactions containing $3.0 \mu \mathrm{l}$ of purified plasmid DNA, $10.2 \mu \mathrm{l}$ of sterile distilled water, $1.5 \mu \mathrm{l}$ of $10 \times$ reaction buffer and $0.3 \mu$ of EcoRI restriction endonuclease. Plasmid DNA was digested at $37^{\circ} \mathrm{C}$ for $3 \mathrm{~h}$, and $10 \mu \mathrm{l}$ of the digested plasmid DNA was elec- 
trophoresed on a $3 \%(1.5 \%$ agarose and $1.5 \%$ low melt agarose) agarose gel, stained with ethidium bromide and visualized under UV light.

For the PCR-based screening method, bacterial colonies were picked from agar plates using a sterile wooden toothpick and inoculated into $10 \mu \mathrm{l}$ of sterile water in $200 \mu \mathrm{l}$ plastic strip tubes. Inoculated water samples were boiled for $4 \mathrm{~min}$ at $94^{\circ} \mathrm{C}$, and $0.5 \mu$ of the boiled preparation were used in a PCR reaction using the M13 forward and reverse primers as described by Moss et al. (2006). Following amplification with the M13 primer pair, $3 \mu \mathrm{l}$ of PCR product were electrophoresed on a $2 \%$ agarose gel, stained with ethidium bromide and visualized under UV light as described above.

Prior to sequencing, PCR products from clones containing the correct insert size were treated with shrimp alkaline phosphatase (SAP) and exonuclease I (ExoI) (Amersham Biosciences) in order to degrade nucleotides and single-stranded DNA (primers) remaining after PCR. We combined $5 \mu \mathrm{l}$ of the M13 PCR product with $0.5 \mathrm{U}$ of SAP and $5.0 \mathrm{U}$ of ExoI and incubated at $37^{\circ} \mathrm{C}$ for $30 \mathrm{~min}, 80^{\circ} \mathrm{C}$ for $15 \mathrm{~min}$ and $15^{\circ} \mathrm{C}$ for $5 \mathrm{~s}$.

Plasmid inserts or PCR products of plasmid inserts were sequenced bi-directionally, using the ThermoSequenase labeled primer cycle sequencing kit (Amersham Pharmacia) according to methods described by Reece \& Stokes (2003), or using the Big Dye Terminator kit (Applied Biosystems) with M13 sequencing primers as described by Moss et al. (2006).

Analysis of Perkinsus spp. and molluscan herpesvirus sequences. Perkinsus spp. and molluscan herpesvirus sequences were compared to those deposited in GenBank and those compiled previously by researchers at VIMS, using BLAST (basic local alignment search tool) searches (Altschul et al. 1990) of the National Center for Biotechnology Information (NCBI) database.

Available ITS region sequences from Perkinsus spp. and ' $\mathrm{A}$ ' fragment sequences of molluscan herpesviruses were downloaded from GenBank and included in phylogenetic analyses of the sequences obtained in this study. Representative Perkinsus spp. ITS region sequences included the following: $P$. marinus AY295177-AY295186; P. chesapeaki AF091541, AF440466, AF440468, AY876302, AY876304, AY876306, AY876308, AY876312, AY876314; P. olseni AF441207AF441211, AF441213-AF441217; P. mediterraneus AY487834-AY487843; P. honshuensis DQ516696DQ516702 and P. qugwadi AF15128. Representative molluscan herpesvirus sequences included the genome sequence of OsHV-1, AY509253, and sequences AY459364 and AY459362.

Perkinsus spp. ITS region and molluscan herpesvirus sequences were aligned separately using the CLUSTAL-W algorithm (Thompson et al. 1994) in
MacVector 8.0.1, with open and extend gap penalties of 7 and 3, respectively. Neighbor-joining and parsimony analyses of Perkinsus spp. ITS region sequences were conducted using PAUP*4b10.0 (Swofford 2002). Bootstrap analyses were done with 10 random additions of 100 bootstrap replicates, with gaps treated as missing data. For jackknife analyses, 30\% deletion was done with 10 random additions and 100 replicates, with gaps treated as missing data.

\section{RESULTS}

\section{Host identifications}

The species identification of each individual was determined using the molecular genetic PCR-RFLP key developed by Cordes \& Reece (2005) (Table 1). Although only the host species Crassostrea ariakensis was targeted for this study, and the animals were identified by fishermen and scientists in Asia as C. ariakensis, many other Crassostrea species, and even a Saccostrea species, were found among the samples (Zhang et al. 2005, Cordes \& Reece 2005).

\section{PCR-based screening results}

PCR-based screening results from locations in Japan, China and Korea (Fig. 1) revealed that molluscan herpesviruses and Perkinsus spp. parasites are widespread in Asian populations of Crassostrea ariakensis, C. hongkongensis and other oyster species found at the same sites (Table 2). The Itoki River (Japan), Shouchang River and Chengcun (China), and Kahwa and Sumjin River (South Korea) sites had the highest prevalences of molluscan herpesviruses among locations sampled (Table 2). There was DNA evidence of Perkinsus spp. infections in C. ariakensis and other bivalve species at several Japanese and Chinese sampling sites. DNA from an undescribed Perkinsus species was detected in all samples collected between 1999 and 2005 from sites in southern China, indicating that the parasite is endemic to that region (Table 2).

Perkinsus marinus DNA was detected in VIMS hatchery stocks of Crassostrea ariakensis, however, none of the oysters screened from the VIMS hatchery was PCR-positive for molluscan herpesviruses (Table 2).

\section{Histological screening results}

The viral, bacterial, protistan and metazoan parasites detected in oysters by histopathology at 8 sites 
Table 2. Perkinsus spp. and molluscan herpesvirus (HV) pathogens. Prevalence data based on molecular assays. Only samples where either one or both of these pathogens were detected are listed. The bivalve species infected with either pathogen at a sampling site are indicated. See Fig. 1 and Table 1 for locations in SE Asia. VIMS = Virginia Institute of Marine Sciences, WCA = west coast USA C. ariakensis, NCA = F1 northern China C. ariakensis, C. = Crassostrea

\begin{tabular}{|c|c|c|c|c|c|c|c|c|}
\hline Year & Sample & $\mathrm{N}$ & $\begin{array}{l}\text { No. HV } \\
\text { positive }\end{array}$ & $\begin{array}{c}\% \mathrm{HV} \\
\text { prevalence }\end{array}$ & $\begin{array}{c}\text { No. } \\
\text { Perkinsus } \\
\text { sp. positive }\end{array}$ & $\begin{array}{c}\text { \% Perkinsus } \\
\text { sp. } \\
\text { prevalence }\end{array}$ & $\begin{array}{l}\text { Perkinsus } \\
\text { species }\end{array}$ & $\begin{array}{l}\text { Bivalve } \\
\text { species }\end{array}$ \\
\hline \multicolumn{9}{|l|}{ Japan } \\
\hline 1999 & Itoki River, Kyushu (IR) & 50 & 13 & 26.0 & 9 & 18.0 & P. olseni & C. ariakensis \\
\hline \multirow[t]{3}{*}{2005} & Mie Prefecture (JPAB05) & 172 & 5 & 2.9 & 0 & - & & C. ariakensis \\
\hline & & 29 & 2 & 6.9 & 0 & - & & C. gigas \\
\hline & & 45 & 2 & 4.4 & 0 & - & & C. sikamea \\
\hline \multicolumn{9}{|c|}{ South Korea } \\
\hline 2004 & Kahwa River (KR) & 35 & 10 & 28.6 & 0 & - & & C. ariakensis \\
\hline 2004 & Sumjin (SR) & 20 & 8 & 40.0 & 0 & - & & C. ariakensis \\
\hline 2004 & $\begin{array}{l}\text { Kanghwa Island, Inchon } \\
\text { (IN) }\end{array}$ & 20 & 1 & 5.0 & 0 & - & & C. ariakensis \\
\hline \multicolumn{9}{|c|}{ (सx+7) } \\
\hline 1999 & $\begin{array}{l}\text { Yellow River, Bohai Sea, } \\
\text { Shandong (YR) }\end{array}$ & 43 & 0 & - & 2 & 4.7 & P. olseni & C. ariakensis \\
\hline 2002 & Tong'an, Fujian (TA) & 28 & 0 & - & 1 & 3.6 & Undescribed & C. ariakensis \\
\hline 1999 & $\begin{array}{l}\text { Yamen River, Zhuhai, } \\
\text { Guangdong (Z) }\end{array}$ & 50 & 5 & 10.0 & 5 & 10.0 & P. olseni & C. hongkongensis \\
\hline 1999 & $\begin{array}{l}\text { Shouchang River, Yangjiang, } \\
\text { Guangdong (YJ) }\end{array}$ & 50 & 10 & 20.0 & 1 & 2.0 & P. olseni & C. hongkongensis \\
\hline 2002 & $\begin{array}{l}\text { Chengcun, Yangxi, } \\
\text { Guangdong }(\mathrm{CH})\end{array}$ & 37 & 4 & 10.8 & 6 & 16.2 & Undescribed & C. hongkongensis \\
\hline 2002 & $\begin{array}{l}\text { Shenzhen, Guangdong } \\
\text { (SZ) }\end{array}$ & 13 & 0 & - & 1 & 7.6 & Undescribed & C. hongkongensis \\
\hline 2002 & $\begin{array}{l}\text { Guandu, Zhanjiang, } \\
\text { Guangdong, (GD_C) }\end{array}$ & 35 & 0 & - & 4 & 11.4 & Undescribed & C. hongkongensis \\
\hline 2002 & $\begin{array}{l}\text { Guandu, Zhanjiang, } \\
\text { Guangdong (GD_N) }\end{array}$ & 25 & 0 & - & 3 & 12.0 & Undescribed & C. hongkongensis \\
\hline \multirow[t]{2}{*}{2003} & Zhanjiang, Guangdong, & 1 & 0 & - & 1 & 100.0 & Undescribed & C. ariakensis \\
\hline & $(\mathrm{ZJ})$ & 70 & 0 & - & 32 & 45.7 & Undescribed & C. hongkongensis \\
\hline \multirow[t]{2}{*}{1999} & Dafen River, Beihai, & 26 & 0 & - & 9 & 34.6 & Undescribed & C. ariakensis \\
\hline & Guangxi Zhuang (DR) & 24 & 1 & 4.1 & 2 & 8.3 & Undescribed & C. hongkongensis \\
\hline \multirow[t]{2}{*}{2002} & Podi, Beihai, & 14 & 0 & - & 2 & 14.3 & Undescribed & C. ariakensis \\
\hline & Guangxi Zhuang $(\mathrm{PO})^{\mathrm{a}}$ & 24 & 0 & - & 2 & 8.3 & Undescribed & C. hongkongensis \\
\hline 2003 & $\begin{array}{l}\text { Beihai, Guangxi Zhuang } \\
\text { (BC) }\end{array}$ & 59 & 0 & - & 11 & 18.6 & Undescribed & C. hongkongensis \\
\hline \multirow[t]{2}{*}{2005} & Beihai, Guangxi Zhuang & 12 & 0 & - & 4 & 33.3 & Undescribed & C. ariakensis \\
\hline & (BC_05) & 101 & 0 & - & 36 & 35.6 & Undescribed & C. hongkongensis \\
\hline 2003 & $\begin{array}{l}\text { Lingshui, Hainan, } \\
\text { Guangxi Zhuang (HN) }\end{array}$ & 19 & 0 & - & 12 & 63.2 & Undescribed & $\begin{array}{l}\text { Pinctada margaritifera } \\
\text { P. martensii, unknown } \\
\text { sp. - not distinguished }\end{array}$ \\
\hline 2002 & VIMS NCA & 49 & 0 & - & 10 & 20.4 & P. marinus & C. ariakensis \\
\hline 2003 & VIMS WCA & 50 & 0 & - & 1 & 2.0 & P. marinus & C. ariakensis \\
\hline
\end{tabular}

sampled in 2002 are listed in Table 3 and illustrated in Figs. 2 \& 3. Most parasites were uncommon. Although molluscan herpesvirus DNA was detected by PCR in 4 of 37 animals screened from one of the samples that was also examined by histology, there was no histological evidence of herpes viral infection. In addition to the parasites listed in Table 3, a sample of 33 Crassostrea hongkongensis from southern China collected in 2003 had 18 of 26 female oysters (69\%) infected with a Steinhausia-like microsporidian in the ova (Fig. 2D). Unfortunately, the exact source location for this sample is unknown.

Among the 17 oysters sampled from Beihai (China) in 2005 that tested positive for Perkinsus spp. infections by PCR, only one showed lesions typical of Perkinsus sp. when examined histologically. In oyster BC05Ca-20, there were numerous mature Perkinsus sp. signet ring trophozoites of 5 to $10 \mu \mathrm{m}$ diameter, 

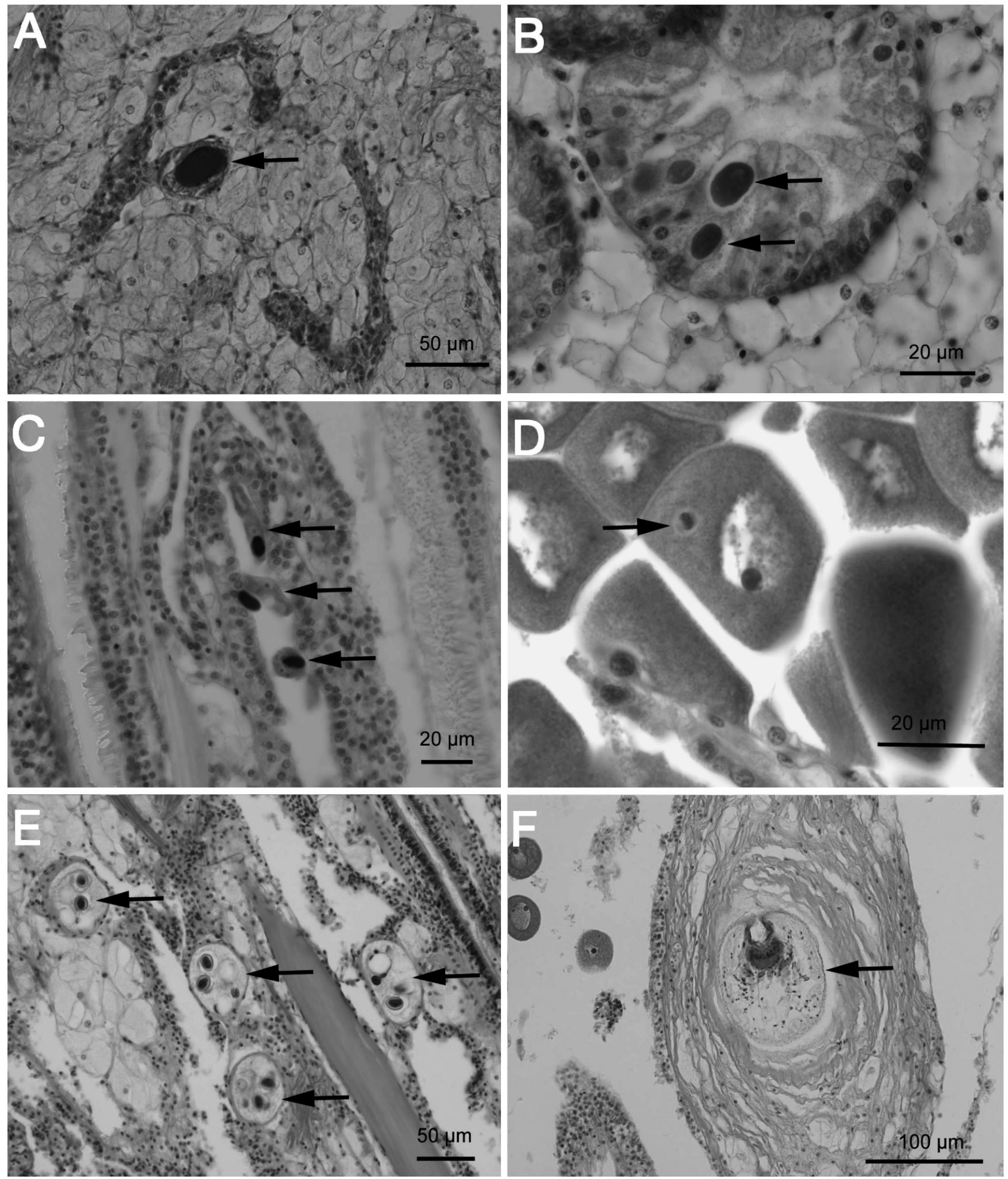

Fig. 2. Parasites observed by histopathology in Crassostrea sp. in China. (A) Viral gametocytic hypertrophy (arrow) in gonad of wild C. hongkongensis from Guandu, Zhanjiang, China. (B) Chlamydia-like inclusions (arrows) in digestive tubules of wild Crassostrea hongkongensis from Guandu, Zhanjiang, China. (C) Ciliates (arrows) attached to gill epithelium in cultured C. hongkongensis from Chengcun, Yangxi, Guangdong, China. (D) Steinhausia-like microsporidian (arrow) in ovum of wild C. hongkongensis from southern China. (E) Spores of Nematopsis-like gregarines (arrows) in cultured C. hongkongensis from Guandu, Zhanjiang, China. (F) Encapsulated metacestode (arrow) in gill tissue of wild C. hongkongensis or C. ariakensis from Dafen River, Beihai, Guangxi Zhuang, China 
Table 3. Histological analysis of oysters collected at 7 locations in China in 2002. See Fig. 1 and Table 1 for locations

\begin{tabular}{|c|c|c|c|c|c|c|c|c|}
\hline Sampling location & $\mathrm{N}$ & $\begin{array}{l}\text { Natural } \\
(\mathrm{N}), \\
\text { Cultured } \\
\text { (C) }\end{array}$ & $\begin{array}{c}\text { Viral } \\
\text { gametocytic } \\
\text { hypertrophy }\end{array}$ & $\begin{array}{l}\text { Chlamydia } \\
\text {-like } \\
\text { organisms }\end{array}$ & $\begin{array}{l}\text { Perkinsus } \\
\text { spp. }\end{array}$ & Ciliates & $\begin{array}{l}\text { Nematopsis } \\
\text { sp. }\end{array}$ & Cestodes \\
\hline Dajiawa, Shandong & 29 & $\mathrm{~N}$ & 0 & 0 & 0 & 4 & 0 & 0 \\
\hline Longhai, Fujian & 28 & $\mathrm{C}$ & 0 & 3 & 0 & 2 & 0 & 0 \\
\hline Tong'an, Fujian & 29 & $\mathrm{~N}$ & 0 & 1 & 0 & 2 & 11 & 1 \\
\hline Chengcun, Yangxi, Guangdong & 31 & $\mathrm{C}$ & 0 & 1 & 1 & 2 & 0 & 1 \\
\hline Shenzhen, Guangdong & 26 & $\mathrm{~N}$ & 0 & 1 & 0 & 1 & 0 & 0 \\
\hline Guandu, Zhanjiang, Guangdong & 30 & $\mathrm{~N}$ & 1 & 1 & 0 & 0 & 9 & 0 \\
\hline Guandu, Zhanjian, Guangdong & 60 & $\mathrm{C}$ & 1 & 6 & 3 & 0 & 14 & 0 \\
\hline Dafen River, Beihai, Guangxi Zhuang & 30 & $\mathrm{~N}$ & 0 & 1 & 0 & 2 & 0 & 6 \\
\hline Podi, Beihai, Guangxi Zhuang & 30 & $\mathrm{C}$ & 0 & 2 & 2 & 2 & 0 & 5 \\
\hline
\end{tabular}


Fig. 3. (A) Mayer's hematoxylin and eosin-stained histological section of a Crassostrea hongkongensis oyster showing Perkinsus sp. cells (arrows) in the stomach epithelium. (B) In situ hybridization with the Perkinsus sp. genus-specific probe to Perkinsus sp. cells (arrows) in the stomach epithelium

subdividing 5 to $10 \mu \mathrm{m}$ diameter schizonts, and clusters of multiple immature sibling trophozoites of 3 to $4 \mu \mathrm{m}$ diameter (Fig. 3). Perkinsus sp. parasite cells (552) enumerated in one section occurred (1) in multifocal stomach epithelium lesions $(43 \%)$, (2) rare lesions in digestive gland epithelia, (3) among con- nective tissues of the mantle ( $27 \%)$, the visceral mass $(15 \%)$ and gills $(10 \%)$ and (4) systemically circulating both free and phagocytosed within host hemocytes in the oyster vasculature $(3 \%)$.

\section{ISH results}

In situ hybridization probes designed to target Perkinsus species hybridized only to Perkinsus sp. cells in oyster samples that were PCR positive for Perkinsus sp. DNA. Fig. 3 shows 2 consecutive sections from Crassostrea hongkongensis from Beihai (China) BC05Ca-20 (described above) infected with the undescribed Perkinsus species. Fig. 3A is a Mayer's hematoxylin and eosin-stained section showing Perkinsus sp. cells in the stomach epithelium of the oyster. Fig. 3B shows positive in situ hybridization with the genusspecific probe to Perkinsus sp. cells. The Perkinsus genus-specific probe labeled cells in connective tissues of the gills and mantle, as well as in the epithelia of intestine and stomach. In situ hybridization reactions conducted without probe produced no signal in tissues of the same host oyster.

\section{Perkinsus spp. ITS region sequences}

ITS region PCR amplification products were sequenced from a selected number of positive oyster samples. All sequences were deposited in GenBank (Table 4). Sequencing of the ITS region amplicons from the genus Perkinsus assay indicated that the Chesapeake Bay native P. marinus was found in VIMS hatchery stocks of Crassostrea ariakensis. This is not surprising, since hatchery-reared oysters are exposed to water coming from the adjacent York River, which is within the native range of $P$. marinus. ITS region sequences from oysters from the NCA and WCA 
hatchery stocks formed a monophyletic clade with known P. marinus sequences, with $100 \%$ bootstrap support in both neighbor joining distance analysis and in maximum parsimony analysis (Figs. 4 \& 5). Perkinsus sp. ITS region sequences amplified from DNAs extracted from $C$. ariakensis and C. hongkongensis oysters collected from several Asian sites, including the Yamen and Yellow rivers (China) and the Itoki River, Kyushu (Japan) formed a monophyletic clade with known $P$. olseni ITS region sequences in both neighbor joining distance analysis and maximum parsimony analysis (100\% bootstrap support) (Figs. 4 \& 5).

Crassostrea ariakensis and C. hongkongensis collected from locations in China along the southern coast from Tong'an, Fujian to the Dafen River, Beihai, appeared to be infected with an undescribed Perkinsus species. The genus-specific Perkinsus spp. primers amplified unique nucleotide sequence fragments of approximately 689 bp from numerous oysters. We sequenced 42 clones from 16 individual oysters selected from 6 different samples, and they were $99.3 \%$ similar (uncorrected- $p$ ) to each other. Overall, 28 of the 42 clones $(67 \%)$ shared a common ITS rRNA sequence, while the other 14 clones all were all unique. BLAST analyses of GenBank suggested that these were Perkinsus sp. sequences. Pairwise distances and molecular phylogenetic analyses confirmed that these sequences were closely related to those of known Perkinsus species. In both neighbor joining and maximum parsimony analyses, these new parasite ITS region sequences grouped with those of known Perkinsus spp. (Figs. 4 \& 5). Mean pairwise distances (uncorrected-p) of ITS region nucleotide sequences within known Perkinsus spp. ranged from $0.2 \%$ in the undescribed Perkinsus sp. to $1.6 \%$ variation in $P$. chesapeaki. Only one ITS region nucleotide sequence was available for $P$. qugwadi, therefore mean intraspecific ITS variation could not be calculated. The ITS region of this new Perkinsus sp. was most distantly related to P. qugwadi $(63.6 \%$ to $63.7 \%$ similarity), and most closely related to the recently described species, P. honshuensis (89.0\% to $89.8 \%$ similarity) (Table 5). Nucleotide sequences from this apparently new parasite taxon form a well-supported sister group (100\% bootstrap support within this species) to the larger Perkinsus spp. clade that includes P. marinus, $P$. mediterraneus and P. olseni (Figs. 4 \& 5).

Table 4. Perkinsus spp. GenBank accession numbers associated with ITS rRNA and molluscan herpesvirus (HV) sequences generated in this study. See Fig. 1 and Table 1 for locations in SE Asia. VIMS = Virginia Institute of Marine Sciences, WCA = west coast USA $C$. ariakensis, NCA = F1 northern China $C$. ariakensis

\begin{tabular}{|c|c|c|}
\hline Pathogen & Source & GenBank accession numbers \\
\hline Perkinsus olseni & Itoki River, Kyushu, Japan (IR) & EF204075, EF204076 \\
\hline Perkinsus olseni & $\begin{array}{l}\text { Yellow River, Bohai Sea, } \\
\text { Shandong, China (YR) }\end{array}$ & EF204073, EF204074 \\
\hline Perkinsus olseni & $\begin{array}{l}\text { Yamen River, Zhuhai, Guangdong, } \\
\text { China (Z) }\end{array}$ & EF204070-EF204072 \\
\hline Undescribed Perkinsus sp. & Tong'an Fujian, China (TA) & EF204046-EF204050 \\
\hline Undescribed Perkinsus sp. & $\begin{array}{l}\text { Chengcun, Yangxi, Guangdong, } \\
\text { China }(\mathrm{CH})\end{array}$ & EF204034, EF204035, EF204043 \\
\hline Undescribed Perkinsus sp. & Shenzhen, Guangdong, China (SZ) & $\begin{array}{l}\text { EF204015-EF204018, EF204029-EF204031, EF204036, } \\
\text { EF204038, EF204039, EF204041 }\end{array}$ \\
\hline Undescribed Perkinsus sp. & $\begin{array}{l}\text { Guandu, Zhanjiang, Guangdong, } \\
\text { China (GD) }\end{array}$ & EF204022, EF204051-EF204056 \\
\hline Undescribed Perkinsus sp. & $\begin{array}{l}\text { Dafen River, Beihai, Guangxi } \\
\text { Zhuang, China (DR) }\end{array}$ & $\begin{array}{l}\text { EF204021, EF204024-EF204028, EF204040, EF204044, } \\
\text { EF204045 }\end{array}$ \\
\hline Undescribed Perkinsus sp. & $\begin{array}{l}\text { Podi, Beihai, Guangxi Zhuang, } \\
\text { China (PO) }\end{array}$ & $\begin{array}{l}\text { EF204019, EF204020, EF204023, EF204032, EF204033, } \\
\text { EF204042 }\end{array}$ \\
\hline Perkinsus marinus & VIMS hatchery (WCA) & EF204008-EF204011 \\
\hline Perkinsus marinus & VIMS hatchery (NCA) & EF204012-EF204014 \\
\hline $\mathrm{HV}$ & $\begin{array}{l}\text { Ariake Sea, Mie, } \\
\text { Japan (JPAB05) }\end{array}$ & EF221836-EF221839 \\
\hline HV & $\begin{array}{l}\text { Kahwa River, } \\
\text { South Korea (KR) }\end{array}$ & EF221840 \\
\hline $\mathrm{HV}$ & $\begin{array}{l}\text { Sumjin River, } \\
\text { South Korea (SR) }\end{array}$ & EF221841 \\
\hline HV & $\begin{array}{l}\text { Yamen River, Zhuhai, Guangdong, } \\
\text { China (Z) }\end{array}$ & EF221843 \\
\hline $\mathrm{HV}$ & $\begin{array}{l}\text { Chengcun, Yangxi, Guangdong, } \\
\text { China }(\mathrm{CH})\end{array}$ & EF221842 \\
\hline $\mathrm{HV}$ & $\begin{array}{l}\text { Shouchang River, Yangjiang, } \\
\text { Guangdong, China (YJ) }\end{array}$ & EF221844 \\
\hline
\end{tabular}




\section{Molluscan herpesvirus sequences}

Molluscan herpesvirus DNA was found in Crassostrea ariakensis populations at a site in the Itoki River, Ariake Bay (Japan), sampled in 1999, and was also found in the 2005 samples taken from Mie Prefecture (Japan) near the first sampling site. A portion of oysters collected at the Kahwa River and Sumjin River

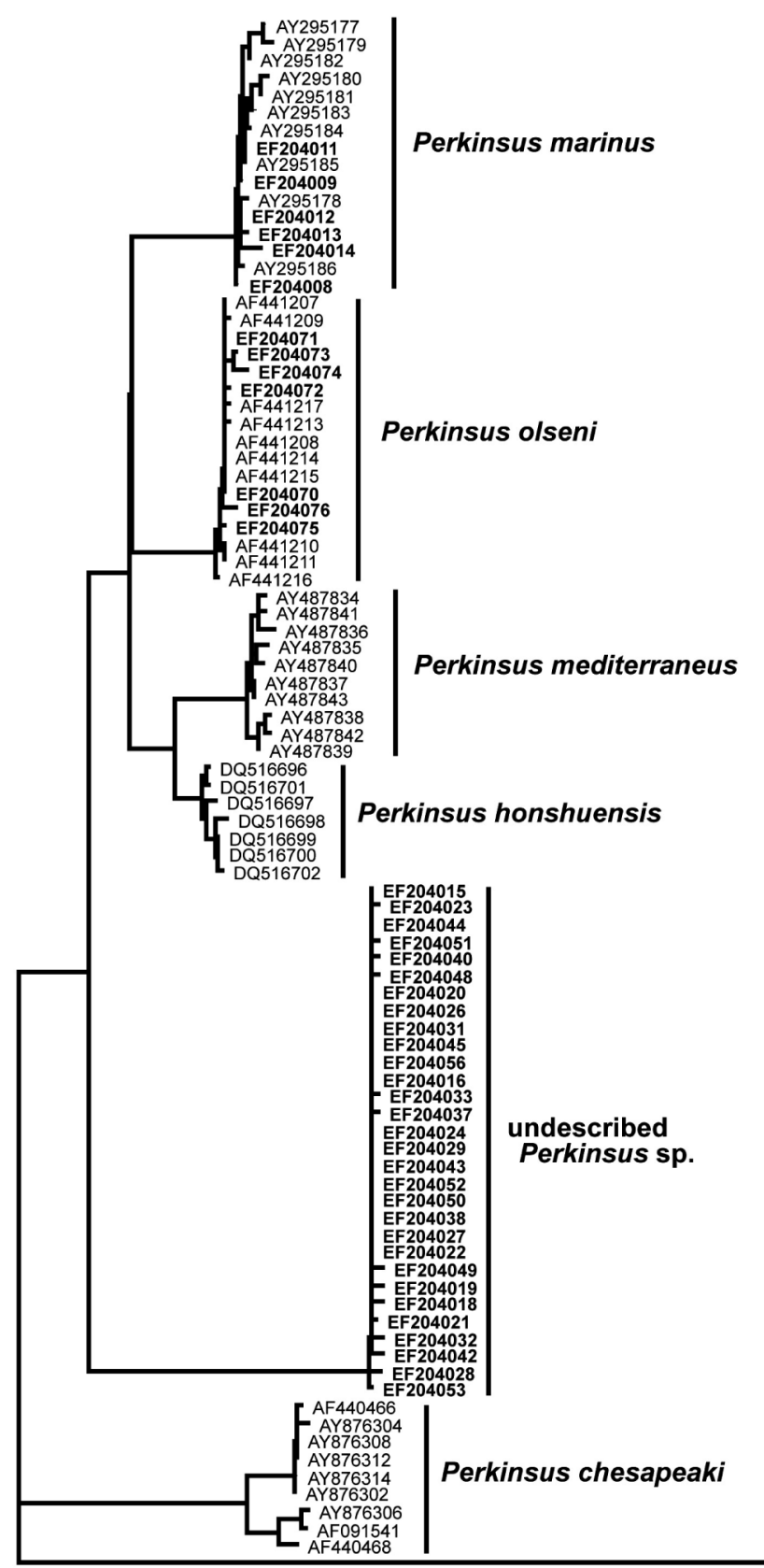

sampling sites (South Korea) as well as in the Yamen River, Shouchang River, Dafen River, and Chengcun sites (China) were also positive for molluscan herpesvirus DNA (Table 3).

Subsets of oysters positive for molluscan herpesvirus DNA from the Yamen River, Shouchang River, and Chengcun (China) and Mie (Japan) were chosen as representatives from those populations, and their herpesvirus DNA was cloned and sequenced. The molluscan herpesvirus DNA amplified from Crassostrea ariakensis collected from the Chinese sites and from the 2 South Korean sites had variations among DNA sequences, and we found polymorphic sequences within and between oysters from different locations. The level of polymorphism between the viral sequences was low $(3.7 \%)$, with a combined total of 34 individual randomly distributed single nucleotide differences over the entire $917 \mathrm{bp}$ sequence from all of the clones analyzed. We also found 3 polymorphic nucleotide sites that generally had consistent polymorphisms across all individuals within a collection site, except for individuals sampled in 2005 from the Ariake Sea, Japan (Fig. 6). The molluscan herpesvirus DNA amplified from $C$. ariakensis specimens collected from the Yamen River and Shouchang River (China) were similar to viral sequences found in French C. gigas (LeDeuff \& Renault 1999, Renault et al. 2000b), sharing a thymine at a polymorphic site $604 \mathrm{bp}$ from the $5^{\prime}$ end of the fragment (primers removed). The molluscan herpesvirus sequences amplified from Chengcun (China) samples of $C$. ariakensis and those from both the Kahwa and Sumjin rivers (South Korea) are similar to that found in C. gigas from Tomales Bay, California (USA) (Friedman et al. 2005) and in the Itoki River (Japan) C. ariakensis, sharing a cytosine at that particular polymorphic site. The viral DNA amplified from the Itoki River samples and from some of the 2005 Ariake Sea (Japan) samples appears to have a unique polymorphism at a site $115 \mathrm{bp}$ from the $5^{\prime}$ end of the fragment, sharing an adenine residue where all other viral sequences share a guanine. From the 2005 Ariake Sea (Japan) samples, molluscan herpesvirus PCR fragments were cloned and sequenced from 3 molluscan herpesvirus-positive $C$. ariakensis oysters and 1 positive C. sikamea. The DNA sequences from these oysters suggest that 2 of the animals (1 specimen of C. ariakensis and the C. sikamea specimen) were infected with the same strain of molluscan herpesvirus found in

\section{Perkinsus}

AF151528 qugwadi

- 0.005 substitutions site ${ }^{-1}$

Fig. 4. Perkinsus spp. ITS rRNA gene sequences. Neighbor joining tree determined by analysis of the ITS gene sequences of known Perkinsus spp. sequences and the ITS gene sequences of those Perkinsus spp. found in oysters collected in Japan and China. GenBank accession numbers associated with each sample from this study (bold) are listed in Table 4 


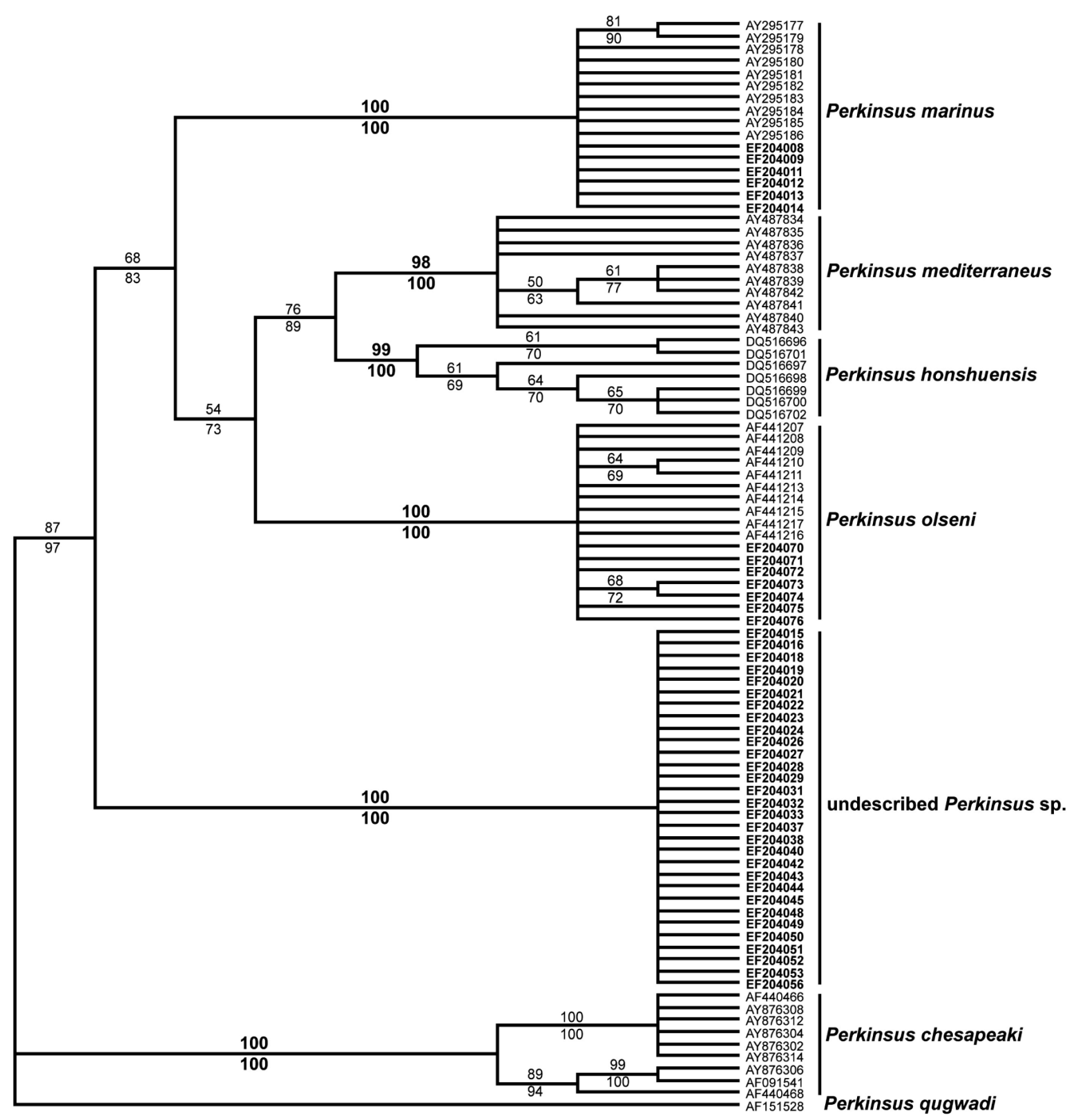

Fig. 5. Perkinsus spp. ITS rRNA gene sequences. Maximum parsimony tree determined by analysis with 100 replicates of 10 random additions of the ITS gene sequences of known Perkinsus spp. sequences and the ITS gene sequences of those Perkinsus spp. found in oysters collected in Japan and China. Maximum parsimony bootstrap support values for each clade are given above the lines and jackknife support values are given below the lines. Bold support values indicate species clades. GenBank accession numbers associated with each sample from this study (bold) are listed in Table 4

the Japanese C. ariakensis collected in 1999 from the Itoki River. The other 2 C. ariakensis specimens were infected with the strain commonly seen in France and parts of China. Viral DNAs amplified from Chengcun (China) and Korean C. ariakensis shared an additional polymorphic site $761 \mathrm{bp}$ from the $5^{\prime}$ end of the A5/A6 fragment. These viral sequences share a guanine at this site, where all other viral sequences share a cytosine.

\section{DISCUSSION}

Several potential disease agents, including 2 different Perkinsus species, molluscan herpesviruses and a Steinhausia-like microsporidian, were detected in oysters collected from sites in Asia where potential Crassostrea ariakensis broodstocks might originate. Standard ICES protocols should minimize the risk of introducing horizontally transmitted pathogens with 
Table 5. Perkinsus spp. Range of sequence similarities and pairwise distances (uncorrected ' $p$ ' values) observed among rDNA ITS region sequences of currently accepted species from GenBank, and those of the undescribed species obtained in this study. The range of observed within-species sequence distance is given across the diagonal. Raw distance value ranges between species are given above the diagonal, and ranges for percent distance values are given below

\begin{tabular}{|c|c|c|c|c|c|c|c|}
\hline \multirow{2}{*}{ Species } & \multirow[b]{2}{*}{ marinus } & \multirow[b]{2}{*}{ chesapeaki } & \multirow{2}{*}{$\begin{array}{l}\text { - Perkinsus } \\
\text { mediterraneus }\end{array}$} & \multirow[b]{2}{*}{ olseni } & \multirow[b]{2}{*}{ honshuensis } & \multirow{2}{*}{$\begin{array}{l}\text { Undescribed } \\
\text { Perkinsus sp. }\end{array}$} & \multirow{2}{*}{$\begin{array}{c}\text { Perkinsus } \\
\text { qugwadi }\end{array}$} \\
\hline & & & & & & & \\
\hline P. marinus & $\begin{array}{c}0.000-0.004 \\
0.4 \%\end{array}$ & $0.119-0.139$ & $0.053-0.069$ & $0.049-0.063$ & $0.052-0.062$ & $0.112-0.126$ & $0.323-0.330$ \\
\hline P. chesapeaki & $11.9-13.9 \%$ & $\begin{array}{c}0.000-0.016 \\
1.6 \%\end{array}$ & $0.134-0.148$ & $0.126-0.138$ & $0.117-0.126$ & $0.156-0.175$ & $0.342-0.350$ \\
\hline P. mediterraneus & $5.3-6.9 \%$ & $13.4-14.8 \%$ & $\begin{array}{c}0.000-0.007 \\
0.7 \%\end{array}$ & $0.050-0.065$ & $0.029-0.040$ & $0.119-0.129$ & $0.331-0.335$ \\
\hline P. olseni & $4.9-6.3 \%$ & $12.6-13.8 \%$ & $5.0-6.5 \%$ & $\begin{array}{c}0.000-0.003 \\
0.3 \%\end{array}$ & $0.049-0.060$ & $0.107-0.119$ & $0.333-0.336$ \\
\hline P. honshuensis & $5.2-6.2 \%$ & $11.7-12.6 \%$ & $2.9-4.0 \%$ & $4.9-6.0 \%$ & $\begin{array}{c}0.000-0.006 \\
0.6 \%\end{array}$ & $0.102-0.110$ & $0.327-0.331$ \\
\hline $\begin{array}{l}\text { Undescribed } \\
\text { Perkinsus sp. }\end{array}$ & $11.2-12.6 \%$ & $15.6-17.5 \%$ & $11.9-12.9 \%$ & $10.7-11.9 \%$ & $10.2-11.0 \%$ & $\begin{array}{c}0.000-0.002 \\
0.2 \%\end{array}$ & $0.363-0.364$ \\
\hline P. qugwadi & $32.3-33.0 \%$ & $34.2-35.0 \%$ & $33.1-33.5 \%$ & $33.3-33.6 \%$ & $32.7-33.1 \%$ & $36.3-36.4 \%$ & $\begin{array}{c}0.0^{\mathrm{a}} \\
0.0 \%^{\mathrm{a}}\end{array}$ \\
\hline
\end{tabular}

\begin{tabular}{|c|c|c|c|c|c|c|c|c|c|c|c|c|c|c|c|c|c|c|c|c|c|c|c|c|c|c|c|c|}
\hline & 110 & & & & 115 & & & & 12 & 600 & & & & 605 & & & & 510 & 755 & & & & 760 & & & & & 765 \\
\hline consensus & $A$ & C & C & $A \quad A$ & $A G$ & $A$ & $A$ & A $T$ & $T \quad G$ & C & $\mathrm{G}$ & G & G T & $\mathrm{T} A$ & $G$ & $\mathrm{~T}$ & $\mathrm{~T}$ & G & $\mathrm{T}$ & $\mathrm{T}$ & $T A$ & $A C$ & C A & $C$ & $\mathrm{~T}$ & $C$ & $T$ & C \\
\hline France AY459362 & . & . & . & . . . & . . & . & . . & . . & . & . & . & . & . & . . & . & . & . & . & . & . & . & . . & . & . & . & . & - & \\
\hline lifornia, USA AY459364 & . & . & . & . . & . . & . & . . & . & . . & $\cdot$ & . & . & . $\mathrm{C}$ & C. & . & . & . & . & . & . & . & . . & . . & . & . & . & . & \\
\hline KR Korea & . & . & . & . . & . . & . & . & 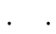 & . & . & . & . & c & C. & . & 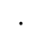 & . & . & . & . & . & . & . . & G & . & . & . & \\
\hline SR20 Korea & . & . & - & . & . & . & . & . & . & . & . & . & $c$ & C. & . & . & ${ }^{\circ}$ & . & . & . & & . & . . & G & . & . & . & \\
\hline CHChina & . & . & . & . & . & . & . & . & . & 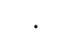 & . & . & . & C. & . & . & . & . & . & . & & . . & . . & G & . & . & . & \\
\hline ina & . & . & . & . . & . . & . & . . & . & . & . & . & . & . & . . & . & . & . & . & . & . & & . . & . . & . & . & . & . & \\
\hline a & . & . & . & . . & . . & . & . . & . . & . & . & . & . . & . & . . & . & . & . . & . & & . & & . & . & . & . & . & & \\
\hline JPAB05 42 Japan & . & . & . & . . & . & . & . . & . . & . & . & . & . & . & $\cdot$. & . & . & . . & . & . & . & . . & . . . & . & . & . & . & . & \\
\hline JPAB05 $54 \mathrm{~J}$ & . & . & . & . . . & . . & . & . & . . & . & . & . & . & . & $\cdot$ & . & . &. & . & . & . & . . & . & . & - & - & $\cdot$ & . & \\
\hline JPAB05 161 Japan & . & . & . & . & . A & . & . . & . & . & . & . & . & . & . & . & . & . . & . & & . & . . & . & . & . & . & $\cdot$ & . & \\
\hline JPAB05 177 Japan & . & . & . & . & . $A$ & 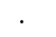 & ${ }^{\circ}$ & . & . & . & $\cdot$ & ${ }^{\circ}$ & 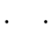 & . & . & $\cdot$ & . & $\cdot$ & & . & $\theta^{\circ}$ & . & . & 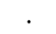 & . & . & & \\
\hline IR Japan & . & & & . . & . $A$ & & . . & . . & 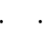 & & & & & & & & & & & & & & & & & & & \\
\hline
\end{tabular}

Fig. 6. Alignment of molluscan herpesvirus 'A' region sequences isolated from oysters showing the polymorphic sites unique to viral sequences at each location. Viral sequences found in France and in Tomales Bay, California, (USA) have been deposited previously in GenBank, and accession numbers are listed accordingly. For other sample codes, see Table 1

the host, since broodstock would be held under strict quarantine conditions, and only progeny of oysters brought to the USA would be introduced into the environment. However, neither the ICES protocols, nor a mechanical procedure such as cleansing gametes to remove superficial parasites, would prevent transmission of pathogens if they infect the gametes themselves. If vertical transmission of any pathogen identified in this survey occurred, they could be introduced to the Chesapeake Bay by vertical transmission from infected broodstock to F1 or F2 C. ariakensis progeny oysters, with the potential for serious negative impacts to already depleted native oyster populations. In addition, C. ariakensis could act as a reservoir host for exotic pathogens that may be introduced by other means. For example, ballast water may have been the source of a possible exotic Bonamia sp. that caused a severe mortality event during 2003 in triploid C. ariakensis deployed for experimental purposes in North Carolina, USA waters (Burreson et al. 2004), but has not been documented to infect local native bivalves. The possibility of vertical transmission of viruses among aquatic organisms is recognized (Bootland et al. 1991, Lo et al. 1997, Tsai et al. 1999), and recent transmission studies in France with C. gigas detected OsHV-1 in 3 successive generations of oysters (Barbosa-Solomieu et al. 2005). In our study, 3 genetic variants of molluscan herpesviruses were detected by PCR.

Two of the pathogens observed histologically pose a threat of introduction to Chesapeake Bay via infected broodstock. Viral gametocytic hypertrophy and the 
Steinhausia-like microsporidian were both observed in oyster ova. Viral gametocytic hypertrophy has been reported in Crassostrea virginica from Chesapeake Bay (Farley 1978), and a Steinhausia-like microsporidian has been reported in the clam Macoma balthica in Chesapeake Bay (Farley 1977). The parasites observed in Asian oysters, however, may be strains or species different from those in Chesapeake Bay, and could pose problems if introduced. There is substantial evidence for vertical transmission of some microsporidian parasites of invertebrate hosts (Kelly et al. 2003, Galbreath et al. 2004, Vizoso \& Ebert 2004), therefore indicating a real possibility for vertical transmission of these Asian pathogens.

Although there is no current evidence to suggest that Perkinsus sp. parasites may be vertically transmitted, and therefore might not be introduced to a new area through importation of small numbers of infected broodstock that are held in quarantine, Karlsson (1991) found protozoan cells that were described as 'Perkinsus-like', but were not a true Perkinsus sp., in male and female scallop gonads. Subsequent infection of the larvae post-spawning was observed, suggesting the possibility of vertical transmission (Karlsson 1991, Whyte et al. 1993). ICES protocols are being followed; however the potential for vertical transmission of the pathogens observed in this study and the associated risks of introducing the non-native host must be recognized. Consistent and careful disease testing of deployed oysters may be required if an introduction occurs. It should be noted that there was no evidence of molluscan herpesviruses in the current VIMS hatchery stocks of $C$. ariakensis that we screened, and although Perkinsus sp. DNA was detected in these samples, it was $P$. marinus DNA, a native species. There is currently no evidence of $P$. olseni or the new undescribed Perkinsus species in the VIMS stocks.

Most parasites observed in the histological analyses conducted here (Table 3) were generally uncommon, and are unlikely to be introduced to a new area via infected broodstocks. Histological observations indicated tissue tropisms by Perkinsus sp. pathogens among both connective tissues and digestive system epithelia of oysters from Beihai, China. These observations are consistent with the detection of Perkinsus sp. DNAs in this sample using molecular tools (see below).

Molecular detection assays identified Perkinsus spp. and molluscan herpesvirus DNA in many of the samples surveyed. $P$. olseni DNA was detected in several samples of Asian Crassostrea ariakensis and C. hongkongensis, and is known to be widely distributed among molluscs in the Pacific and eastern Atlantic oceans (Lester \& Davis 1981). Following synonymization with $P$. atlanticus (Murrell et al. 2002), P. olseni has been reported to infect a variety of hosts from around the world (Villalba et al. 2005), including the blacklipped and the green-lipped abalone in Australia (Lester \& Davis 1981), the carpet shell clam in Portugal (Azevedo 1989), and the Manila clam in Spain, Portugal, northern China, Korea, and Japan (Dungan \& Reece 2006). The discovery of $P$. olseni in C. ariakensis and $C$. hongkongensis in Japan and northern China expands the currently known geographic and host distribution of that parasite.

In addition to Perkinsus olseni, a previously undescribed Perkinsus species was found in populations of Crassostrea ariakensis and C. hongkongensis in southern China, as well as in some pearl oysters and unidentified bivalves. As discussed in several recent publications (Burreson et al. 2005, Reece \& Dungan 2006), molecular methods are the only reliable way to distinguish Perkinsus spp., because host and environmental elements may influence parasite morphological characteristics. ITS region Perkinsus sp. sequences amplified from southern China host sample DNAs grouped with those sequences from other Perkinsus spp. However, as with each of the other species, they form a unique monophyletic clade within the genus, indicating that this is a unique species. The similarity among the sequences within this clade, and the genetic distance between these sequences and those of other Perkinsus spp. are consistent with the distances observed in previous studies that have used the ITS region sequences to discriminate species or strains (Brown et al. 2004, Burreson et al. 2005, Dungan \& Reece 2006). Sequencing of multiple gene regions is recommended to confirm Perkinsus spp. phylogenies based on the ITS rRNA region. To date, phylogenies that were based on other regions, including the large subunit ribosomal RNA and actin gene sequences, have confirmed results obtained using ITS rRNA (Dungan \& Reece 2006, Dungan et al. 2007).

More than 30 yr ago Farley et al. (1972) reported, based on transmission electron microscopy, a herpeslike virus infecting Crassostrea virginica oysters from Maine. A recent survey of oysters from the Atlantic, Gulf of Mexico and Pacific coasts of the USA, which used molecular diagnostic tools designed originally to detect OsHV-1, indicated that a herpes-like virus is currently found only on the Pacific coast of the United States in Tomales Bay, California and not along the Atlantic or Gulf of Mexico coasts (Friedman et al. 2005). Molluscan herpes-like viruses also occur in France (Nicolas et al. 1992, Comps \& Cochennec 1993, Renault et al. 1994, 2000a, 2001, Arzul et al. 2002), Australia (Hine \& Thorn 1997), New Zealand (Hine \& Thorn 1997, Hine et al. 1998), and Taiwan (Chang et al. 2005). Previously, at least 2 genetic strains of molluscan herpesviruses were recognized; with DNA sequence polymorphisms in the 'A' region distinguish- 
ing between the original strain (OsHV-1) found in France, another French variant was described later (Arzul et al. 2001), and a recently described variant strain was found in California (Friedman et al. 2005). Based on our observation of 3 total polymorphic sites within the 'A' region, we suggest that there are at least 2 different genetic strains of molluscan herpesvirus in Japan, one strain in Korea and 2 strains in China.

Initial sequencing of molluscan herpesvirus DNA detected in Crassostrea ariakensis from sites in Korea and in C. hongkongensis in Chengcun (China) suggested, based on the site at $604 \mathrm{bp}$, that these oysters could be infected with the same genetic strain that was detected in C. gigas from Tomales Bay, California (Friedman et al. 2005). However, additional DNA sequencing revealed that the viral DNAs amplified from oysters in Chengcun (China) and from Korean C. ariakensis share an additional polymorphic site, making them different from the California molluscan herpesvirus strain. Interestingly, molluscan herpesvirus sequences found in oysters from Shouchang River and Yamen River (China) had the same 'A' region sequence as OsHV-1 that was first detected in C. gigas from France (Le Deuff \& Renault 1999, Renault et al. 2000b). However, molluscan herpesvirus sequences from Japanese oysters have a unique pattern of differences at the 3 polymorphic sites, suggesting that the 2 Japanese molluscan herpesvirus strains could be unique to that geographic region. Sequencing of additional gene regions of the molluscan herpesvirus found in Asia may further discriminate strains suggested by the polymorphisms observed here in the ' $\mathrm{A}$ ' fragment. Overall, this study expands the current known host geographic range of molluscan herpesviruses to include Japan, China and Korea, where it infects C. ariakensis, C. hongkongensis, C. gigas and C. sikamea.

Acknowledgements. This research was supported by Virginia Sea Grant College Program award NA96RG0025 and NOAA/NMFS awards NA17FU2891 and NA04NMF4570431. Collection assistance was provided by X. Du of Zhanjiang Ocean University, PR China; J. Higano of the Environmental Management Division, National Research Institute of Aquaculture, Fisheries Research Agency, Mie, Japan; X. Guo of Rutgers University; H. An, National Fisheries Research and Development Institute, Pusan, Korea; and R. Carnegie and K. Johnson of VIMS. Oyster species identification assistance was kindly provided by J. Xiao of VIMS. Histological services and diagnoses were provided in part by R. Crockett and S. Denny of VIMS. VIMS contribution number 2876.

\section{LITERATURE CITED}

Allen SK Jr (2005) Stalemate over the new oyster. Virginia Mar Res Bull 37(2):2-16

Altschul SF, Gish W, Miller W, Meyers EW, Lipman DJ (1990) Basic local alignment search tool. J Mol Biol 215:403-410
Andrews JD, Hewatt WG (1957) Oyster mortality studies in Virginia. II. The fungus disease caused by Dermocystidium marinum in oysters of Chesapeake Bay. Ecol Monogr 27:1-26

Arzul I, Nicolas JL, Davidson AJ, Renault T (2001) French scallops: a new host for Ostreid herpesvirus-1. Virology 290:342-349

Arzul I, Renault T, Thebault A, Gerard A (2002) Detection of oyster Herpes Virus DNA and proteins in asymptomatic Crassostrea gigas adults. Virus Res 84:151-160

Audemard C, Ragone Calvo LM, Paynter KT, Reece KS, Burreson EM (2006) Real-time PCR investigation of parasite ecology: in situ determination of oyster parasite Perkinsus marinus transmission dynamics in lower Chesapeake Bay. Parasitol 132:827-842

Azevedo C (1989) Fine structure of Perkinsus atlanticus n. sp. (Apicomplexa, Perkinsea) parasite of the clam Ruditapes decussatus from Portugal. J Parasitol 75:627-635

Batista FM, Arzul I, Pepin JF, Ruano F, Friedman CS, Boudry P, Renault T (2007) Detection of ostreid herpesvirus 1 DNA by PCR in bivalve mollusks: a critical review. J Virol Meth 139:1-11

Barbosa-Solomieu V, Miossec L, Vazquez-Juarez R, Ascencio-Valle F, Boudry P, Renault T (2005) Ostreid herpesvirus 1 detection among three successive generations of Pacific oysters (Crassostrea gigas). Virus Res 107:47-56

Bootland LM, Dobos P, Stevenson RMW (1991) The IPNV carrier state and demonstration of vertical transmission in experimentally infected brook trout. Dis Aquat Org 10: 13-21

Brown G, Hudson KL, Reece KS (2004) Multiple polymorphic sites at the ITS and ATAN loci among and within cultured isolates of Perkinsus marinus. J Eukaryot Microbiol 51: 312-320

Burreson EM, Ragone Calvo LM (1996) Epizootiology of Perkinsus marinus disease of oysters in Chesapeake Bay, with emphasis on data since 1985. J Shellfish Res 15: $17-34$

Burreson EM, Stokes NA, Carnegie RB, Bishop MJ (2004) Bonamia sp. (Haplosporidia) found in non-native oysters, Crassostrea ariakensis, in Bogue Sound, North Carolina. J Aquat Anim Health 16:1-9

Burreson EM, Reece KS, Dungan CF (2005) Molecular, morphological, and experimental evidence support the synonymy of Perkinsus chesapeaki and Perkinsus andrewsi. J Eukaryot Microbiol 52:258-270

Calvo GW, Luckenbach MW, Allen SK Jr, Burreson EM (1999) A comparative field study of Crassostrea gigas and Crassostrea virginica in relation to salinity in Virginia. J Shellfish Res 18:465-473

Calvo GW, Luckenbach MW, Allen, SK Jr., Burreson EM (2001) A comparative field study of Crassostrea ariakensis (Fujita 1913) and Crassostrea virginica (Gmelin) in relation to salinity in Virginia. J Shellfish Res 20: 221-229

Casas SM, Villalba A, Reece KS (2002) Study of perkinsosis in the carpet shell clam Tapes decussates in Galacia (NW Spain). I. Identification of the aetiological agent and in vitro modulation of zoosporulation by temperature and salinity. Dis Aquat Org 50:51-65

Chang PH, Kuo ST, Lai SH, Yang HS, Ting YY, Hsu CL, Chen HC (2005) Herpes-like virus infection causing mortality of cultured abalone Haliotis diversicolor supertexta in Taiwan. Dis Aquat Org 65:23-27

Choi KS, Park KI (1997) Report on the occurrence of Perkinsus sp. in the Manila clams, Ruditapes philippinarum in Korea. J Aquaculture 10:227-237 
Comps M, Cochennec N (1993) A herpes-like virus from the European oyster Ostrea edulis L. J Invertebr Pathol 62: 201-203

Cordes JF, Reece KS (2005) Genetic identification of oyster species based on restriction fragment-length polymorphism (RFLP) analysis of two molecular markers amplified using the polymerase chain reaction (PCR). J Shellfish Res 24:319

Da Ros L, Cazonier WJ (1985) Perkinsus, a protistan threat to bivalve culture in the Mediterranean basin. Bull Eur Assoc Fish Pathol 5:23-27

Dungan $\mathrm{CF}_{\text {, }}$ Reece KS (2006) In vitro propagation of two Perkinsus spp. parasites from Japanese manila clams Venerupis philippinarum and description of Perkinsus honshuensis n. sp. J Eukaryot Microbiol 53:316-326

Dungan CF, Hamilton RM, Hudson KL, McCollough CB, Reece KS (2002) Two epizootic diseases in Chesapeake Bay commercial clams, Mya arenaria and Tagelus plebius. Dis Aquat Org 50:67-78

Dungan CF, Reece KS, Moss JA, Hamilton RM, Diggles BK (2007) Perkinsus olseni in vitro isolates from the New Zealand clam Austrovenus stutchburyi. J Eukaryot Microbiol 54:263-270

Elston RA, Dungan CF, Meyers TR, Reece KS (2004) Perkinsus sp. infection risk for Manila clams, Venerupis philippinarum (A. Adams and Reeve, 1850) on the Pacific coast of North and Central America. J Shellfish Res 23: 101-105

Farley CA (1977) Neoplasms in estuarine mollusks and approaches to ascertain causes. In: Kraybill HF, Dawe CJ, Harshbarger JC, Tardiff RG (eds) Aquatic pollutants and biologic effects with emphasis on neoplasia. Ann NY Acad Sci 298:225-232

Farley CA (1978) Viruses and virus like lesions in marine mollusks. Mar Fish Rev 40(10):18-20

Farley CA, Banfield WG, Kasnic JRG, Foster WS (1972) Oyster herpes-type virus. Science 178:759-760

Figueras A, Robledo JAF, Novoa B (1992) Occurrence of haplosporidian and Perkinsus-like infections in carpetshell clams Ruditapes decussates (Linnaeus, 1758) of the Ría de Vigo (Galacia, NW Spain). J Shellfish Res 11: 377-382

Friedman CS, Estes RM, Stokes NA, Burge CA and 5 others (2005) Herpes virus in juvenile Pacific oysters Crassostrea gigas from Tomales Bay, California, coincides with summer mortality episodes. Dis Aquat Org 63:33-41

Galbreath JGMS, Smith JE, Terry RS, Becnel JJ, Dunn AM (2004) Invasion success of Fibrillanosema cragonycis, n.sp., n.g.: a novel vertically transmitted microsporidian parasite from the invasive host Crangonyx pseudogracilis. Int J Parasitol 34:235-244

Goggin CL, Lester RJG (1995) Perkinsus, a protistan parasite of abalone in Australia: a review. Mar Freshw Res 46: 639-646

Grabowski JH, Powers SP, Peterson CH, Powers MJ, Green DP (2003) Consumer ratings of non-native (Crassostrea gigas and Crassostrea ariakensis) vs. native (Crassostrea virginica) oysters. J Shellfish Res 22:21-30

Hedgecock D, Li G, Banks MA, Kain Z (1999) Occurrence of the Kumamoto oyster Crasssostrea sikamea in the Ariake Sea, Japan. Mar Biol 133:65-68

Hine PM, Thorn T (1997) Replication of herpes-like viruses in haemocytes of adult flat oysters Ostrea angasi: an ultrastructural study. Dis Aquat Org 29:189-196

Hine PM, Wesney B, Hay BE (1992) Herpesviruses associated with mortalities among hatchery-reared larval Pacific oysters Crassostrea gigas. Dis Aquat Org 12:135-142
Hine PM, Wesney B, Besant P (1998) Replication of a herpeslike virus in larvae of the flat oyster Tiostrea chilensis at ambient temperatures. Dis Aquat Org 32:161-171

ICES (International Council for the Exploration of the Sea) (2005) Code of practice on the introductions and transfers of marine organisms. ICES, Copenhagen

Karlsson JD (1991) Parasites of the bay scallop, Argopecten irradians Lamark (1819). In: Schumay SE, Sandifer PA (eds) An international compendium of scallop biology and culture. World Aquaculture Workshop no. 1. World Aquaculture Society, Baton Rouge, LA, p 180-190

Kelly A, Hatcher MJ, Dunn AM (2003) The impact of a vertically transmitted microsporidian, Nosema granulosis on the fitness of its Gammarus deubeni host under stressful environmental conditions. Parasitol 126:119-124

Le Deuff RM, Renault T (1999) Purification and partial genome characterization of a herpes-like virus infecting the Japanese oyster, Crassostrea gigas. J Gen Virol 80:1317-1322

Le Deuff RM, Nicola JL, Renault T, Cochennec N (1994) Experimental transmission of herpes-like virus to axenic larvae of the Pacific oyster, Crassostrea gigas. Bull Eur Fish Pathol 14:69

Lester RJG, Davis GHG (1981) A new Perkinsus species (Apicomplexa, Perkinsea) from the abalone Haliotis ruber. J Invertebr Pathol 37:181-187

Lo $\mathrm{CF}_{\text {, }} \mathrm{Ho} \mathrm{CH}$, Chen $\mathrm{CH}$, Liu KF and 9 others (1997) Detection and tissue tropism of white spot syndrome baculovirus (WSBV) in captured brooders of Paneus monodon with a special emphasis on reproductive organs. Dis Aquat Org 30:53-72

Mackin JG, Owen HM, Collier A (1950) Preliminary note on the occurrence of a new protistan parasite, Dermocystidium marinum n. sp. in Crassostrea virginica (Gmelin). Science 111:328-329

Mann R, Burreson EM, Baker PK (1991) The decline of the Virginia oyster fishery in Chesapeake Bay: considerations for introduction of non-endemic species, Crassostrea gigas (Thunberg, 1973). J Shellfish Res 10:379-388

Medlin L, Elwood HJ, Stickel S, Sogin ML (1988) The characterization of enzymatically amplified eukaryotic16S-like rRNA-coding proteins. Gene 71:491-499

Montes J, Durfort M, García-Valero J (2001) Parasitism by the protozoan Perkinsus atlanticus favours the development of opportunistic infections. Dis Aquat Org 46:57-66

Moss JA, Burreson EM, Reece KS (2006) Advanced Perkinsus marinus infections in Crassostrea ariakensis maintained under laboratory conditions. J Shellfish Res 25:65-72

Murrell A, Kleeman SN, Barker SC, Lester RJG (2002) Synonymy of Perkinsus olseni Lester \& Davis, 1981 and Perkinsus atlanticus Azevedo, 1989 and an update on the phylogenetic position of the genus Perkinsus. Bull Eur Assoc Fish Pathol 22:258-265

NRC (National Research Council of the National Academy of Sciences) (2003) Non-native oysters in Chesapeake Bay. National Academies Press, Washington, DC

Nicolas JL, Comps M, Cochennec N (1992) Herpes-like virus infecting Pacific oyster larvae, Crassostrea gigas. Bull Eur Assoc Fish Pathol 12:11-13

Orner DM (2005) Chesapeake Bay office integrated research program symposium report, fiscal year 2004. NOAA Chesapeake Bay Office, Annapolis, MD

Park KI, Choi KS (2001) Spatial distribution of the protozoan parasite Perkinsus sp. found in the Manila clams, Ruditapes phillipinarum, in Korea. Aquaculture 203:9-22

Ray SM (1952) A culture method for the diagnosis of infections with Dermocystidium marinum Mackin, Owen and Collier in oysters. Science 116:360-361 
Reece KS, Dungan CF (2006) Perkinsus sp. infections of marine molluscs. In: Fish health section. Blue book. Suggested procedures for detection and identification of certain finfish and shellfish pathogens, 2005 edn. Chapter 5.2:1-17. Fish Health Section, American Fisheries Society, Bethesda, MD

Reece KS, Stokes NA (2003) Molecular analysis of a haplosporidian parasite from cultured New Zealand abalone Haliotis iris. Dis Aquat Org 53:61-66

Renault T (1998) Infections herpétique chez les invertébrés: détection de virus de type herpès chez les mollusques bivalves marins. Virologie 2:401-403

Renault T, Cochennec N, Le Deuff RM, Chollet B (1994) Herpes-virus infecting Japanese oyster (Crassostrea gigas) spat. Bull Eur Assoc Fish Pathol 14:64

Renault T, Le Deuff RM, Chollet B, Cochennec N, Gerard A (2000a) Concomitant herpes-like virus infections in hatchery reared larvae and nursery-cultured spat Crassostrea gigas and Ostrea edulis. Dis Aquat Org 42:173-183

Renault T, Le Deuff RM, Lipart C, Delsert D (2000b) Development of a PCR procedure for the detection of a herpes-like virus infecting oysters in France. J Virol Meth 88:41-50

Renault T, Lipart C, Arzul I (2001) A herpes-like virus infects a non-ostreid bivalve species: virus replication in Ruditapes philippinarum larvae. Dis Aquat Org 45:1-7

Santmartí MM, García-Valero J, Montes JF, Pech A, Durfort M (1995) Seguimento del protozoo Perkinsus sp., en las poblaciones de Tapes decussatus y Tapes semidecussatus del Delta del Ebro. Actas V Congr Nac Acuicult 5: 260-265

Shaw BL, Battle HI (1957) The gross microscopic anatomy of the digestive tract of the oyster Crassostrea virginica (Gmelin). Can J Zool 35:325-347

Editorial responsibility: Catherine Collins, Aberdeen, UK
Sindermann CJ (1990) Principal diseases of marine fish and shellfish, Vol 2. Academic Press, San Diego, CA

Stokes NA, Burreson EM (1995) A sensitive and specific DNA probe for the oyster pathogen Haplosporidium nelsoni. J Eukaryot Microbiol 42:350-357

Swofford DL (2002) PAUP Phylogenetic analysis using parsimony (and other methods), Ver. 4.0b10. Sinauer Associates, Sunderland, MA

Thompson JD, Higgins DG, Gibson TJ (1994) Improving the sensitivity of progressive multiple sequence alignment through sequence weighting, positions-specific gap penalties and weight matrix choice. Nucleic Acids Res 22:4673-4680

Tsai MF, Kou GH, Liu HC, Liu KF and 5 others (1999) Longterm presence of white spot syndrome virus (WSSV) in cultivated shrimp population without disease outbreaks. Dis Aquat Org 38:107-114

Villalba A, Casas SM, López C, Carballal MJ (2005) Study of perkinsosis in the carpet shell clam Tapes decussates in Galacia (NW Spain). II. Temporal pattern of disease dynamics and association with clam mortality. Dis Aquat Org 65:257-267

Vizoso DB, Ebert D (2004) Within-host dynamics of a microsporidium with horizontal and vertical transmission: Octosporea bayeri in Daphnia magna. Parasitol 28:31-38

Whyte SK, Cawthorn RJ, McGladdery SE, MacMillan RJ, Montgomery DM (1993) Cross-transmission studies of Perkinsus karlssoni (Apicomplexa) from bay scallops Argopecten irradians to native Atlantic Canadian shellfish species. Dis Aquat Org 17:33-39

Zhang Q, Allen SK Jr, Reece KS (2005) Genetic variation in wild and hatchery stocks of the Suminoe oyster (Crassostrea ariakensis) assessed by PCR-RFLP and microsatellite markers. Mar Biotechnol 7:588-599

Submitted: February 23, 2007; Accepted: May 23, 2007 Proofs received from author(s): September 10, 2007 